\title{
An Omphalos from Napata
}

\section{Author(s): F. Ll. Griffith}

Source: The Journal of Egyptian Archaeology, Vol. 3, No. 4 (Oct., 1916), p. 255

Published by: Egypt Exploration Society

Stable URL: http://www.jstor.org/stable/3853536

Accessed: 10-04-2016 10:48 UTC

Your use of the JSTOR archive indicates your acceptance of the Terms \& Conditions of Use, available at

http://about.jstor.org/terms

JSTOR is a not-for-profit service that helps scholars, researchers, and students discover, use, and build upon a wide range of content in a trusted digital archive. We use information technology and tools to increase productivity and facilitate new forms of scholarship. For more information about JSTOR, please contact support@jstor.org.

Egypt Exploration Society is collaborating with JSTOR to digitize, preserve and extend access to The Journal of Egyptian Archaeology 


\title{
AN OMPHALOS FROM NAPATA
}

\author{
By F. LL. GRIFFITH, M.A.
}

With Dr REISNER's kind permission a sketch, made from a photograph, is here given

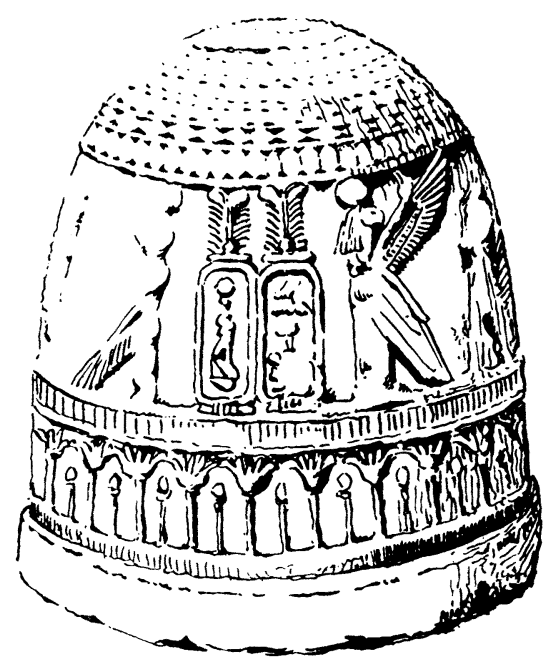
of a remarkable Meroitic monument which he discovered last year at Gebel Barkal, towards the inner end of the great temple of Ammon. It is of sandstone and evidently of moderate size. Its conical shape is precisely that of the omphalos at the oracle of Delphi ${ }^{1}$. In a previous note ${ }^{2}$ I ventured to identify it with the umbilicus-like figure of the god of the Oasis of Ammon which is recorded only by Quintus Curtius in the following description:- "The thing which is worshipped as a god has not the shape that artificers have usually applied to the gods; its appearance is most like an umbilicus, and it is made of an (?) emerald and gems cemented together8." But M. DARESSY had already discovered a strange sack-like form of Ammon of Karnak with which he quite appropriately compared this description of the Ammon in the Oasis4.

Anyhow the present omphalos is unique from Nubia and is probably to be connected with an oracle of Ammon. Perhaps the imitative Nubians took the idea from Delphi. The curved top is decorated as if with strings of beads or pendants, the sides are sculptured with figures of deities and two royal cartouches, and a band of upright lotus buds and flowers encircles the base. The cartouches contain an Egyptian prenomen

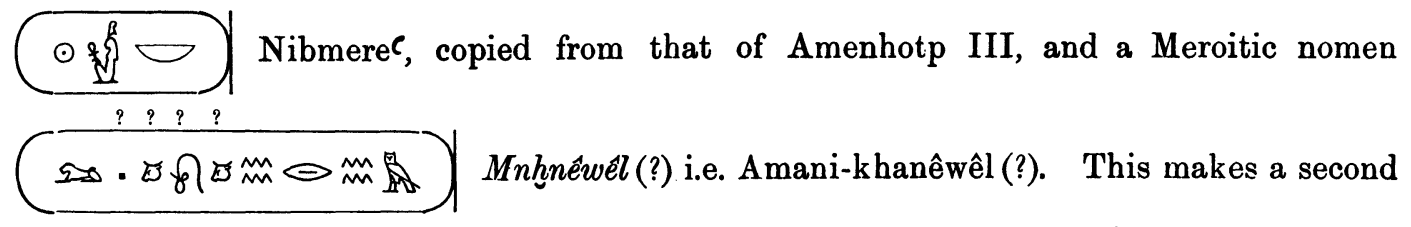
Meroitic Nibmerec, there being already known an Amani-tenmêmize with that prenomen in the shrine of Pyramid A 38 at Meroes. The date of the monument would seem to be round about A.D. 1.

1 Daremberg et Saglio, Dict. des Antiq., s.v. Omphalos.

2 Journal III, p. 221.

3 Curtius iv, 7.

4 Annales du Service des Antiquités Ix, 64.

5 Mer. Inscr. I, nos. 66, 67. 